\title{
Case for diagnosis
}

João Roberto Antonio ${ }^{1}$

Mariana Perez Borim ${ }^{1}$

Guilherme Bueno de Oliveira ${ }^{1}$

\author{
Larissa Cannizza Pacheco de Lucca ${ }^{1}$ \\ Natália Cristina Pires Rossi ${ }^{1}$
}

\section{CASE REPORT}

A 60-year-old woman reports a 5-year history of violaceous and intensely pruritic lesions on the dorsum and scalp, associated with a 2-year history of hair loss. She also reports decreased hair growth in the axillary and inguinal regions in the same period.

Dermatological examination shows small, scaly, erythematous-violaceous, flat papules on the dorsal region; multifocal scarring alopecia areas, with smooth, bright and atrophic surface; discrete hair rarefaction in the axillary and inguinal regions; presence of longitudinal grooves and some depressions on the surface of the nail plate; no oral lesions (Figures 1 and 2). The histopathology of the dorsal lesion is shown in figure $3 \mathrm{~A}$ and that of the scalp is shown in figure $3 \mathrm{~B}$.

The treatment was performed using highpotency corticoids and resulted, after three months, in an improvement of pruritus and a slight lightening of the lesions.

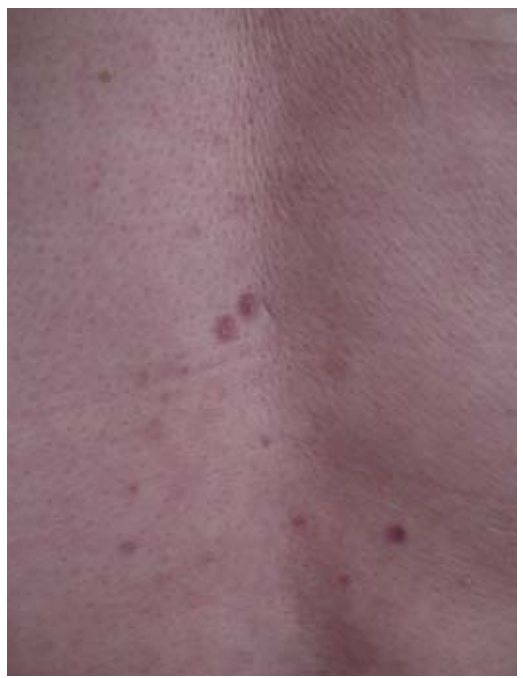

FIGURE 1:

Cutaneous, erythematouspurpuric lesions on the dorsal region

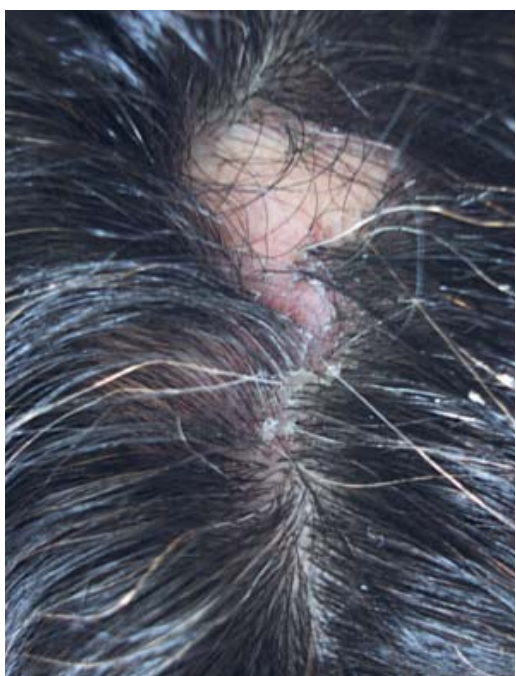

Figure 2:

Perifollicular erythema with desquamation at the vertex of the scalp; cicatricial alopecia and smooth, bright and atrophic surface
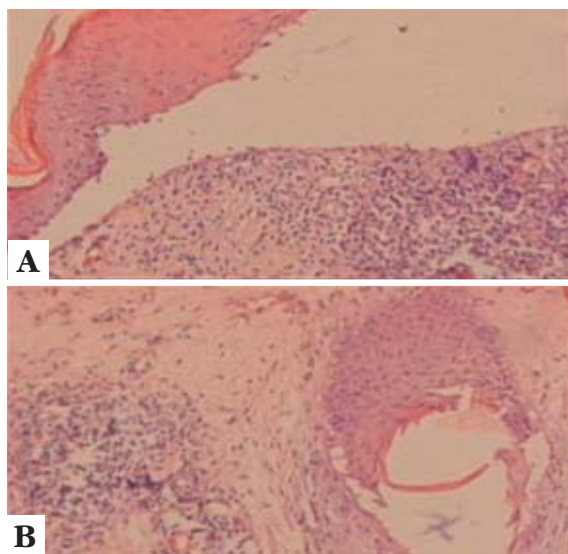

FIGURE 3: A. HE 200x. Interface dermatitis with lichenoid pattern associated with dermo-epidermic detachment and lymphocytic infiltrate in band-like pattern in the upper dermis. B. HE 200x. Detail of partially destroyed follicle, with perifollicular fibrosis and perivascular lymphocytic infiltrate

Received on 19.09.2013.

Approved by the Advisory Board and accepted for publication on 04.12.2013.

* Study conducted at the School of Medicine of São José do Rio Preto (FAMERP) - São José do Rio Preto (SP), Brazil.

Conflict of interest: None

Financial funding: None

School of Medicine of São José do Rio Preto (FAMERP) - São José do Rio Preto (SP), Brazil.

@ 2014 by Anais Brasileiros de Dermatologia 


\section{DISCUSSION}

Graham-Little-Piccardi-Lassueur (GLPL) syndrome is a rare form of Lichen Planus (LP), characterized by the triad: non-scarring hair loss in the inguinal and axillary regions, and follicular spinous or disseminated acuminate papules; typical, cutaneous or mucous LP; and scarring alopecia of the scalp with or without atrophy. These features do not have to be present simultaneously. ${ }^{1-3}$

Its etiopathogenesis is attributed to emotional factors, endocrine disorders, infections, neurological disorders, enzymatic changes, drug use and immune changes. However, its etiology remains unknown. ${ }^{4,5}$ There is a growing body of evidence that the dermatosis represents an autoimmune damage mediated by $\mathrm{T}$ cells against basal keratinocytes expressing autoantigens altered on their surface. ${ }^{1,4}$ Particularly in the case of GLPL, studies have shown the role of inner centromere proteins (INCENP) functioning as autoimmunity stimulating antigens; and Antigenic Mimicry or scattering of epitopes to stimulate a transition from LP to an ulcerative, exanthematous or other rare forms of the disease. ${ }^{6-9}$
Diagnosis is clinical and histopathological. Histological findings, however, are not always specific and conclusive. The most characteristic consists of interface dermatitis with vacuolar degeneration of the basal cell layer and perivascular lymphocytic inflammatory infiltrate in the middle dermis. The striking pigmentary incontinence favors the diagnosis of LP. In the LP of the hair, from the early stages, an inflammatory infiltrate appears around the hair follicles, especially in their upper half; and the follicular destruction occurs at a late stage., ${ }^{2,49}$

Differential diagnosis should be made with other causes of acquired scarring alopecia, such as pseudopelade of Brocq, discoid lupus erythematosus, sarcoidosis, follicular mucinosis, folliculitis decalvans, atrophic keratosis pilaris, graft-versus-host disease, eosinophilic cellulitis, dermatomyositis, lichen sclerosus et atrophicus, scleroderma, mastocytosis, pyoderma gangrenosum, necrobiosis lipoidica and cicatricial pemphigoid. ${ }^{3,5}$

The classic treatment is done with the use of systemic and topical corticosteroids, retinoids, phototherapy, tacrolimus, hydroxychloroquine and cyclosporine, with partial and temporary results. ${ }^{3,8}$

\begin{abstract}
Graham-Little-Piccardi-Lassueur Syndrome is a rare form of Lichen Planus, characterized by the presence of the triad: non-scarring hair loss in the inguinal and axillary regions and follicular spinous or disseminated acuminate papules; typical, cutaneous or mucous LP; and scarring alopecia of the scalp with or without atrophy. These features do not have to be present simultaneously.
\end{abstract}

Keywords: Alopecia; Dermatitis; Lichen planus

\section{REFERENCES}

1. Zegarska B, Kallas D, Schwartz RA, Czajkowski R, Uchanska G, Placek W. GrahamLittle Syndrome. Acta Dermatovenerol Alp Panonica Adriat. 2010;19:39-42.

2. Bolognia JL, Jorizzo JL, Rapini RP. Dermatotologia. In: Shiohara T, Kano Y, editores. Líquen plano e dermatoses liquenóides. Rio de Janeiro: Elsevier Mosby; 2011. p. $159-180$.

3. Romiti N, Dinato SLM, Almeida JRP, Sementilli A, Moraes JM, Ribeiro MCM. Síndrome de Graham-Little-Piccardi-Lassueur. Manifestação cutânea incomum associada a doença renal crônica. Diagn Tratamento. 2005;10:188-90.

4. Berker DAR, Messenger AG, Sinclair RD. Disorders of Hair. In: Burns T, Cox N, Griffiths C, editors. Rook's Textbook of Dermatology. 7th ed. Turin: Black well Publishing; 2004. p.50-1.

5. Ghislain PD, Van Eeckhout P, Ghislain E. Lassueur-Graham Little-Piccardi syndrome: a 20-year followup. Dermatology. 2003;206:391-2.

6. Rodríguez-Bayona B, Ruchaud S, Rodríguez C, Linares M, Astola A, Ortiz M, et al. Auto antibodies against the chromosomal passenger protein INCENP found in a patient with Graham Little-Piccardi-Lassueur syndrome. J Autoimmune Dis. 2007;4:1.

7. Tchernev G, Nenoff P. Antigen mimicry followed by epitope spreading: a pathogenetic trigger for the clinical morphology of lichen planus and its transition to Graham Lassueur Piccardi Little Syndrome and keratosis lichenoides chronica Medical hypotheses or reality? An Bras Dermatol. 2009;84:682-8.
8. Bianchi L, Paro Vidolin A, Piemonte P, Carboni I, Chimenti S. Graham LittlePiccardi-Lassueur syndrome: effective treatment with cyclosporin A. Clin Exp Dermatol. 2001;26:518-20.

9. Steglich RB, Tonoli RE, Pinto GM, Müller FM, Guarenti IM, Duvelius ES. GrahamLittle Piccardi Lassueur syndrome: case report. An Bras Dermatol. 2012;87:775-7.

\author{
MAILING ADDRESS: \\ João Roberto Antonio \\ Avenida Brigadeiro Faria Lima, 5416 - São Manoel \\ 15090-000 - São José do Rio Preto - SP \\ Brazil \\ E-mail:dr.joao@terra.com.br
}

How to cite this article: Antonio JR, Lucca LCP, Borim MP, Rossi NCP, Oliveira GB. Case for diagnosis. GrahamLittle-Piccardi-Lassueur Syndrome. An Bras Dermatol. 2014;89(6):1003-4. 